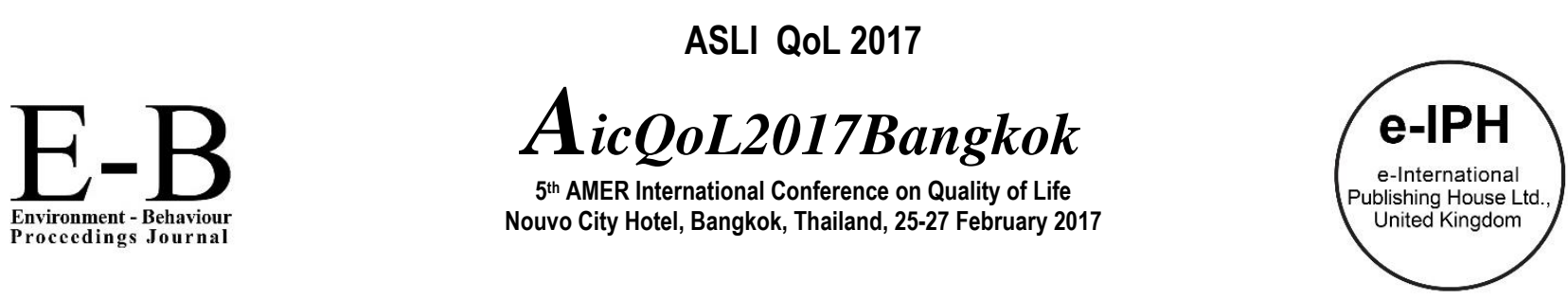

\title{
Unplanned Settlement of Fishing Village Belawan in Medan City, Indonesia
}

\author{
Beny OY Marpaung* \\ Architecture Department. Faculty of Engineering, University of Sumatera Utara \\ Jalan Dr. T. Mansur No. 9, Medan 20155 Sumatera Utara Indonesia
}

\begin{abstract}
Fishermen's settlements in Belawan Medan tend to form unplanned. Social interaction in this village becomes the basis for the establishment of an unplanned settlement. Qualitative method is used in this research. The society's social condition in this village offers a challenge in analyzing social influence towards the establishment of the fishing village in Medan City. The purpose of this research is to find the form of the unplanned settlement that occurred. The results of this research will create a theoretical concept related to the forms of a coastal village. The objective of this research is to produce a theoretical concept regarding unplanned settlement which can be implicated in studying the unplanned settlements in developing countries.
\end{abstract}

Keywords: socio; unplanned; fishing; village

ISSN: 2398-4287C 2017. The Authors. Published for AMER ABRA by e-International Publishing House, Ltd., UK. This is an open access article under the CC BYNCND license (http://creativecommons.org/licenses/by-nc-nd/4.0/). Peer-review under responsibility of AMER (Association of Malaysian Environment-Behaviour Researchers), ABRA (Association of Behavioural Researchers on Asians) and cE-Bs (Centre for Environment-Behaviour Studies), Faculty of Architecture, Planning \& Surveying, Universiti Teknologi MARA, Malaysia.

\subsection{Introduction}

Fishing village in Belawan Medan is an unplanned settlement. The villagers built their residences themselves. The area of this village is the property of Indonesia Port joint-stock company (PT. Pelindo). Every villager who wants to construct buildings in this fishing village has to ask for building permit from the head of a section of the fishing village. If the villagers have gotten the permit, they are then allowed to construct buildings or their houses without any building and construction regulations. The result of this reality is the villagers build and use the lands according to their thoughts and needs. As time flows, more villagers came and built more residences in the village, resulting in the emergence of settlement land use issues. The land use becomes unplanned resulting in the formation of spatial patterns of unplanned settlement, and this tends to create an irregular form of settlement. The influence of social condition in this village affects the development of an unplanned settlement, although visually the village has rundown ambiance. The physical form of an unplanned settlement can be identified as the typology and morphology of the settlement in the village.

\subsection{Social Influence toward the Establishment of an Unplanned Settlement}

The strength of relationships has a role of social life in the establishment of a settlement. Relationships can develop because of social interaction. Social interaction is a process, and its existence affects each other in stating their thoughts, feelings, wishes and anxieties (De Bustillos, Liana, Santosa, \& Napier, 2005). People only establish social relationships with each other because they have the same interest. The pattern of social relationship can form if there are behaviors and relationships that correspondent with the situation and condition of the society. Those systems are social regulations which comprise norms. They are based on the system of social organization that manages community's needs fulfillment to keep the social interaction in the community well-ordered (Larcombe, \& Yan, 2010). In reality, the establishment of a settlement is connected with the norms. The environment as an architectural result is the reflection of society's social and cultural life order (Nasution, \& Zahrah, 2015). The shape of society's life in a settlement is the shape of social interaction among the residents that affects the spatial pattern. Social interaction is an important aspect that can influence the transformation of space into becoming another function according to the needs (Marpaung, \& Harahap, 2016). Based on theories in

\footnotetext{
* Corresponding author. Tel.: +62811617121

E-mail address: beny.marpaung@usu.ac.id
}

ISSN: 2398-4287C 2017. The Authors. Published for AMER ABRA by e-International Publishing House, Ltd., UK. This is an open access article under the CC BYNCND license (http://creativecommons.org/licenses/by-nc-nd/4.0/). Peer-review under responsibility of AMER (Association of Malaysian Environment-Behaviour Researchers), ABRA (Association of Behavioural Researchers on Asians) and cE-Bs (Centre for Environment-Behaviour Studies), Faculty of Architecture, Planning \& Surveying, Universiti Teknologi MARA, Malaysia. DOI: http://dx.doi.org/10.21834/e-bpj.v2i5.612 
sociology and anthropology, aside from organic, personality and culture, the social aspect is one of the factors that underlie a society's regularity. All of them simultaneously form an "integrated total system" which is an artificial environment that represents the identity of the society. In this case, the social aspect is related to structure, function, roles and processes that take place in the corresponding society's life (Ginting, 2016).

\subsection{Research Method}

At first, "Quota Sampling" model is used to determine the key area (Creswell, 2008). Determination of key areas is a method to divide the research area (Fig. 1). Informants or samples are then chosen to act as representatives of the research area. Some criteria of villagers who are chosen as samples or respondents in this research are (1) the ones who know the history of the establishment of the village; (2) the ones who know about the system of social interaction and the values of community life; (3) the ones who have stayed long in the research area; (4) the elderlies and respected figures of the village; (5) public figures who have a role in the development of the environment in the village. The approaches used in the analysis of this research is including identification of the characteristics of villagers' social interaction that forms settlement space, the study of residences pattern (micro), and study of settlement pattern (macro).

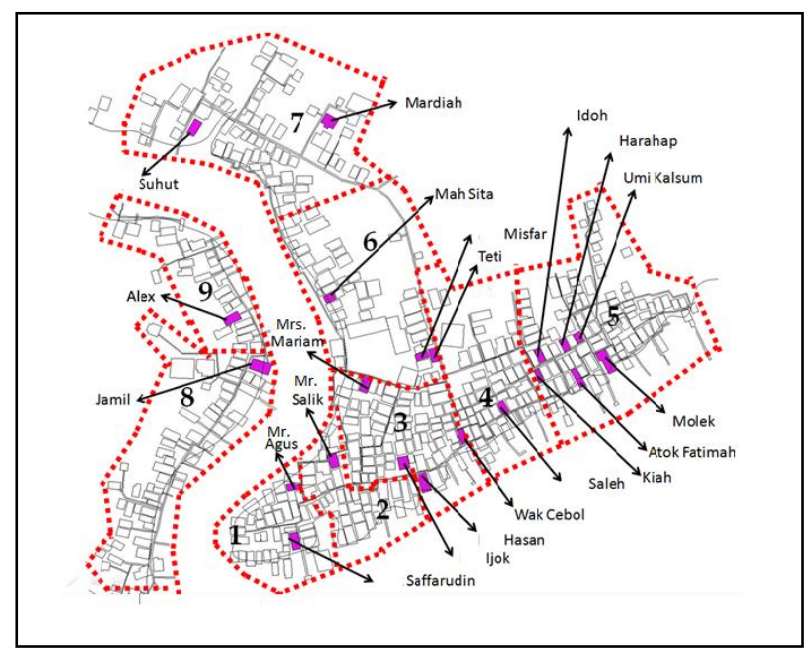

Fig. 1: The names of informants who represent research areas sample

Researchers analyzed the characteristics of social interaction. Researchers identify the behavioral characteristics of living and community interaction with descriptive-explorative methods and approach Behavior Mapping. Physical building, outer space, and the structure of public residential building space using the descriptive method. Analysis of kinship: Kinship is a relationship that describes the family lineage or pedigree. Identification of the kinship that individual relationships with individual and the individual's relationship with the group. Identification using descriptive analysis. This descriptive analysis method explains the kinship between the occupants by connecting to the houses in the area, so the researchers found the pattern of existing buildings in the area. In analyzing the development of settlement patterns, identified a pattern of development and macroeconomic house orientation direction of settlement development trend in the fishing village of Medan Belawan and its impact on the form of dwelling and its environment. Researchers analyzed the use of spaces settlements by connecting function space along the spatial pattern. This method will find elements and elements of spatial patterns are the locations, orientation, scale space, hierarchy, and openness.

\subsection{Discussion}

Belawan Medan Fishing Village is located in Belawan I Village, Medan Belawan Sub-district, Medan City, North Sumatera Province (Fig. 2).

The villagers build their residences in the village based on the characteristic of each region. Many of the building masses are oriented towards the sea, and many are oriented towards the road away from the sea (Fig. 3). The researcher discovers patterns by observing the physical condition of Belawan Medan Fishing Village. The two-sided linear pattern happens through the placement of building along the two sides of circulation at local roads in the settlement. The one-sided linear pattern can be seen from houses or buildings that face rivers or Belawan Sea. Lastly, cluster or circular pattern can be formed through the placement of buildings circling an important public space such as open space, mosque, musalla, and etcetera. The public spaces serve as social interaction places. The forms of social interaction between Belawan Medan Fishing Village villagers can be observed based on three types of relationship: the relationship between individuals, between individuals and groups, and between groups. The social interaction that occurs is the result of the relationships. All of those relationships create certain activities that require space to interact with one another. According to interviews and observations toward social interaction in a genetic relationship, the researcher discovered that there are communications happened inside the house, at house porch, and at the shared yard. However, not all houses in the village have a yard. Shared yards are found in settlement of extended families (Fig. 4), but not in settlement of single families (Fig. 5). 
Naturally, the shapes of the road that exists also have patterns. Those patterns emerge because people always use them. The roads are constructed because the villagers often use them as interaction places (Fig. 6). This reality illustrates that need becomes the basis of typology establishment (Marpaung, 2016). That typology has its characteristic because it forms naturally. As the time flows, the roads are often being made permanent by the villagers and another certain party (Marpaung \& Harahap, 2016).
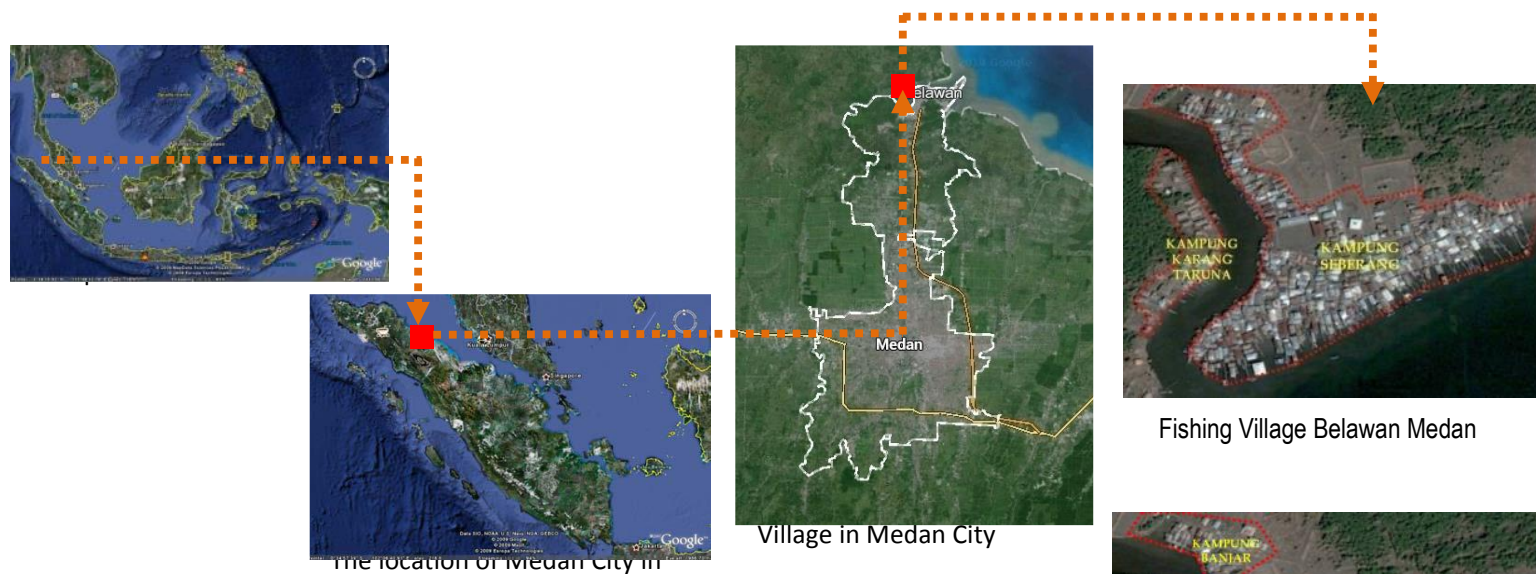

Fishing Village Belawan Medan Sumatera

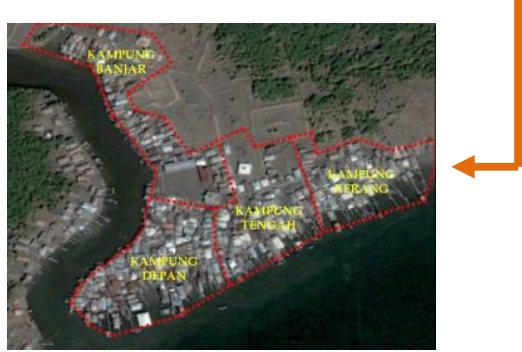

Fishing Village Belawan I Medan consist of 4 area; Depan Village, Tengah village, Banjar Village, and Kerana Villaae

Fig. 2: Research Location Map Source: Google Earth

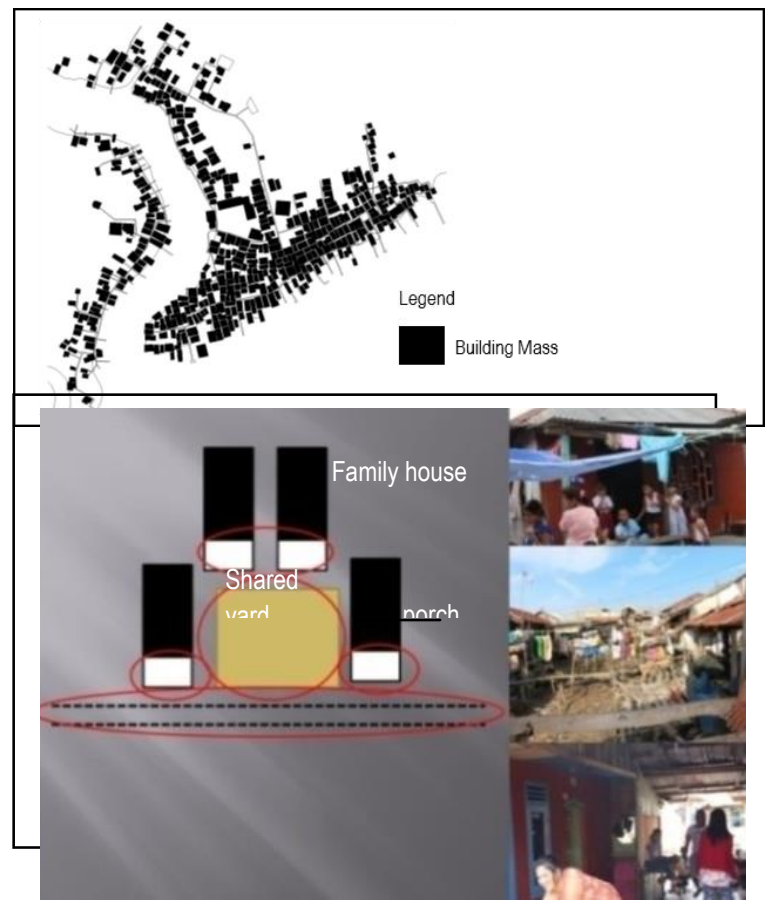

Fig. 4: The shape of shared yard owned by extended family

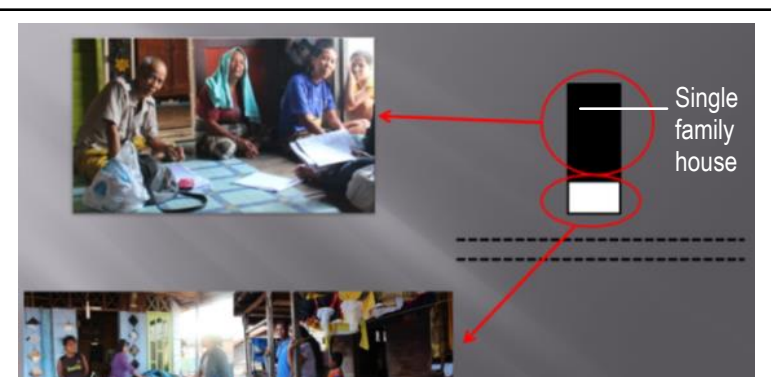


Fig. 5: Shared yards are not found in settlement of single family houses

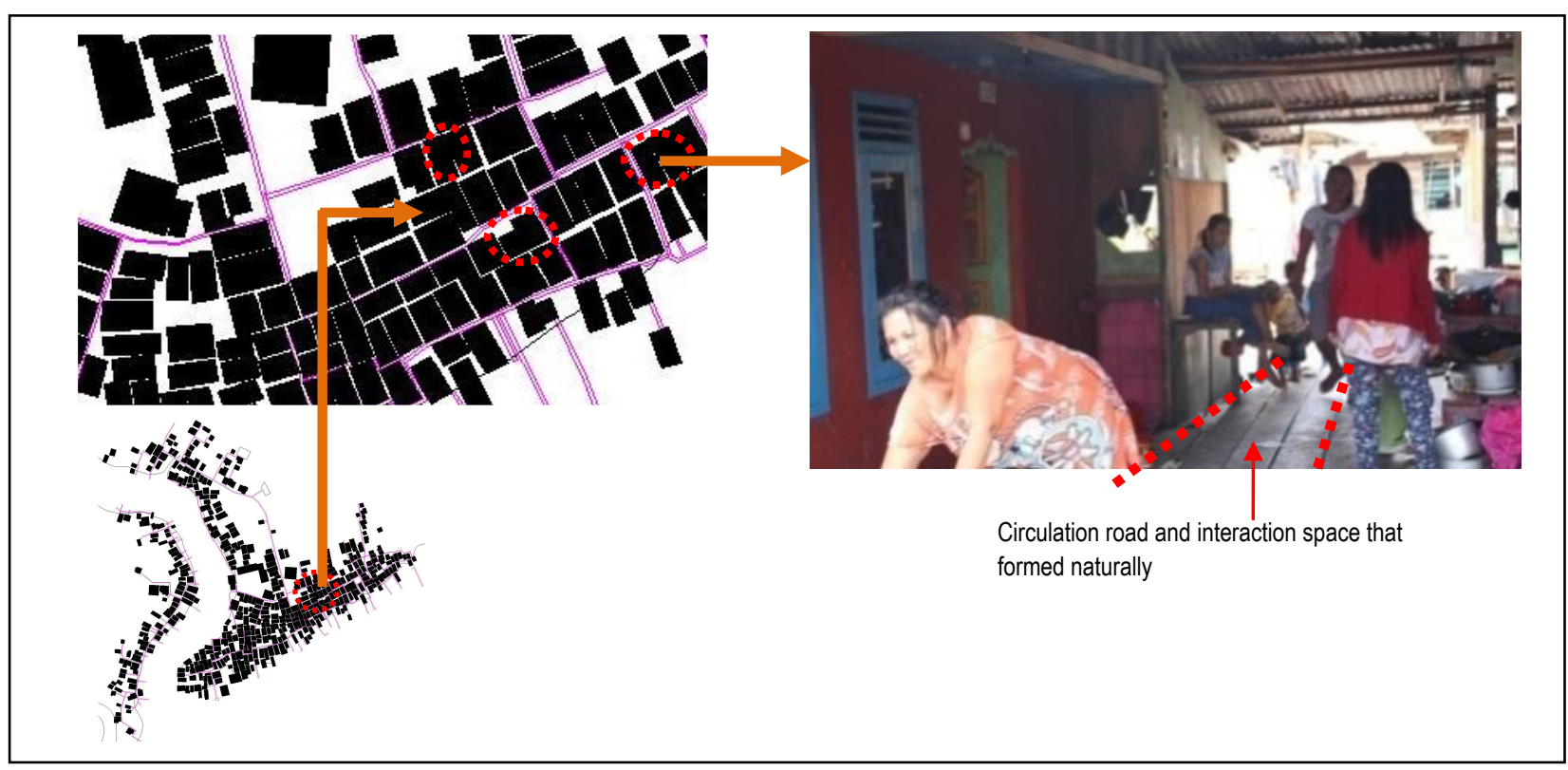

Fig.6: Road between building naturally serves as circulation road and interaction space

Social interaction affects the form of settlement in the fishing village in Belawan Medan. The type of social interaction that affects the establishment of the village settlement most is the interaction among individuals. That type of interaction is divided into two types: the interaction in an extended family and a single family. Social interaction affects the development of the area into becoming a settlement called Belawan Fishing Village. This condition can be identified through every respondent who has stayed long in this village. The villagers divide themselves into groups and settle in the settlement (Fig.7). Those settler groups can form because of genetic relationships. That relationship in a family creates a settler group. Thus, a layout of settlement is created (Besussi, Chin, Batty, \& Longley, 2010). The structure of the layout is the result of a social process.

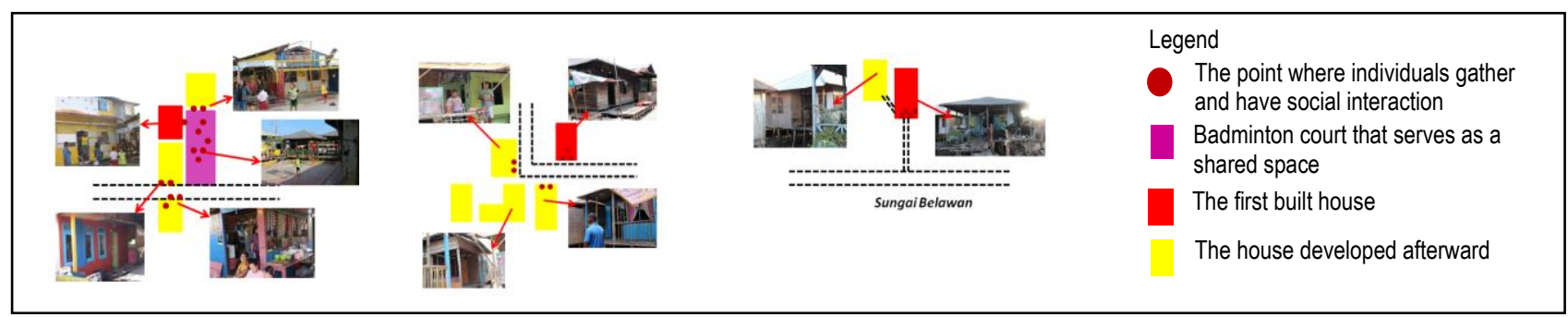

Fig.7: Genetic relationship in extended family results in the forming of settler group

In the beginning, the settlers came to this village to fish at the coast of Belawan. As the times passed, they decided to live in the village, worked as fishermen and brought their children and families to live in there. When the villagers' youngsters have married, they turned out to choose to live close to their parents. That condition illustrates that the bond of genetic relationship is strong. Physically, the youngsters who were already married built their houses close to their parents'. The impact of this condition is the forming of a settler group. In this group, they made social interaction spaces that were used as shared space. Those groups could occur because of the existence of neighborhood relationship which is formed through the activity of helping each other, cooperation, and discussion. 
The strength of neighborhood relationship can be seen from how Belawan Medan Fishing Village villagers can distinguish and interact with their neighbors (Fig.8). Humans as social beings need social interaction with others, not only in a small community such as family but also in a large community such as society. They create their interaction spaces to be able to hold social interaction activities in a big group. The society who lives in the village realizes the importance of interaction with surrounding society, and they build public facilities that can serve as places to be used together for social interaction in a large community in macro range (Fig. 9). Social interaction pattern in neighborhood relationship is based on the identification of respondents who know their neighbors well, and the place has shared spaces equipped with facilities such as badminton court, hall, temporary fish market, mosque, and musalla (Fig.10).

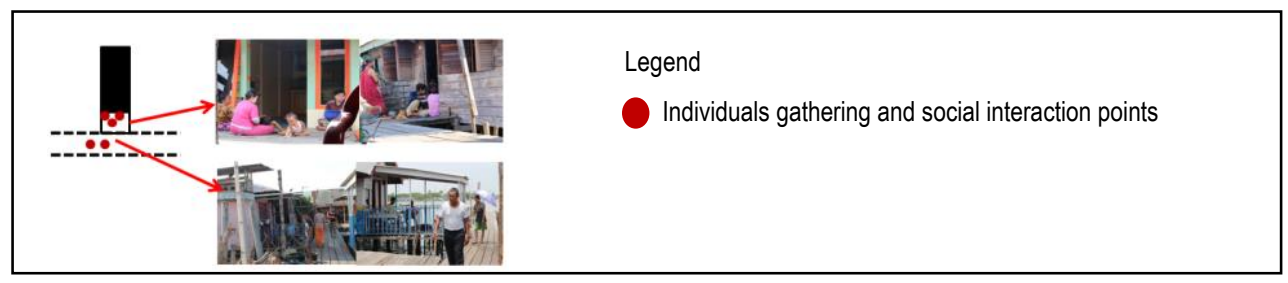

Fig.8: Social interaction occurs at circulation roads and the porch of villagers' houses

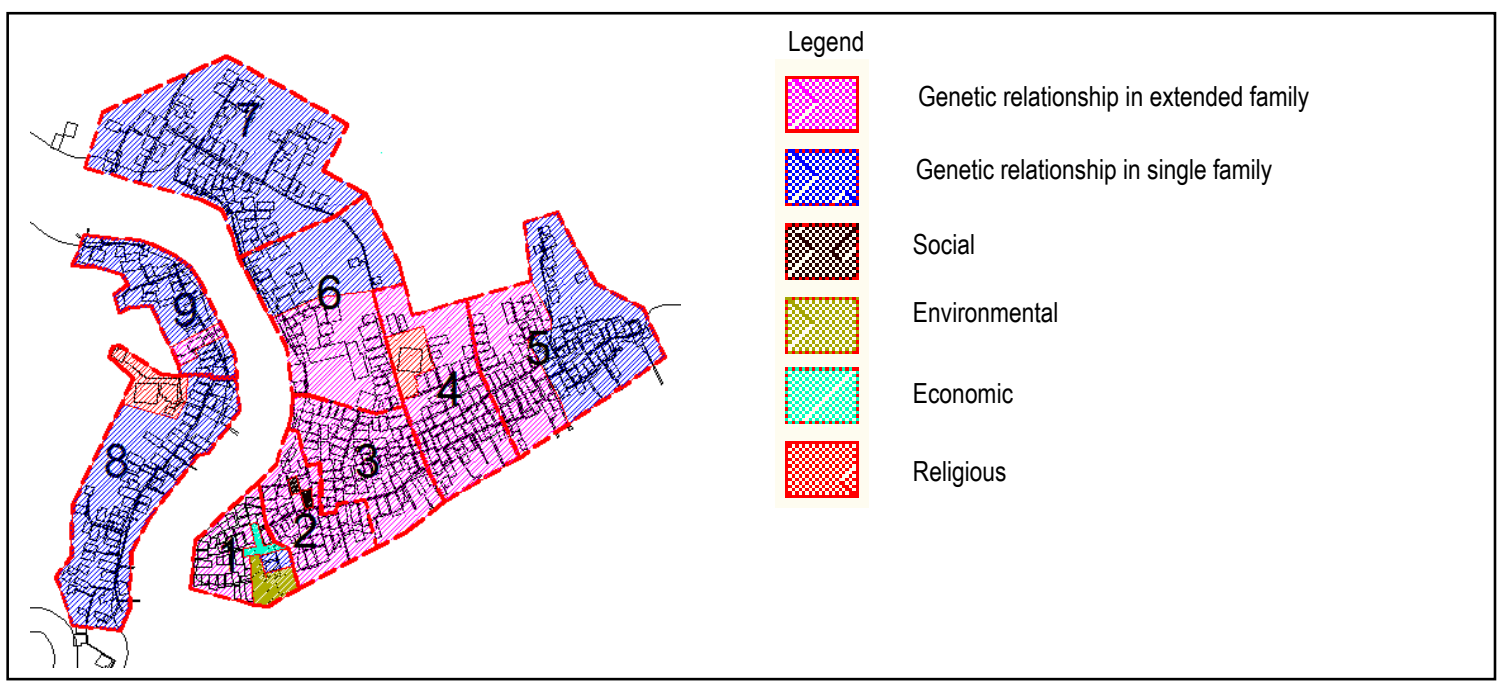

Fig.9: The characteristic of social interaction relationship in each segment

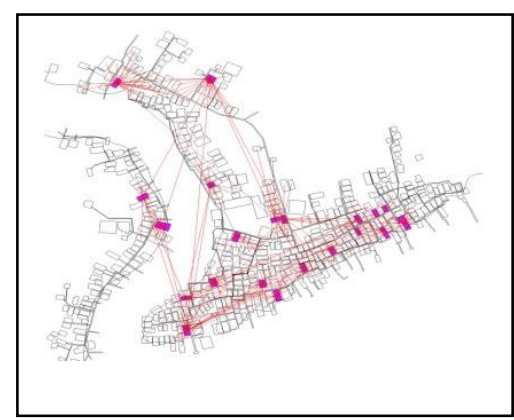

Fig. 10: The pattern of social interaction in neighborhood relationship in the research area

Society's role in religious activities creates some associations such as recitation association (pengajian and perwiritan). And to accommodate those religious activities, the society creates places to practice their religion such as mosque and musalla. They can interact with each other when attending the religious activities. The location of musalla and mosque in the settlement creates a particular spatial pattern (Fig. 11). This fact can be seen from the position of circulation, the placement, and the orientation centered in the interaction space. Human membership in small group namely family, social, institutional and cultural organization group affects regulations in the community. The ways they communicate, interact, handle social work, and create kinship apparently have an effect toward the shape of the settlement environment (Drolet, Robertson, \& Robinson, 2010).

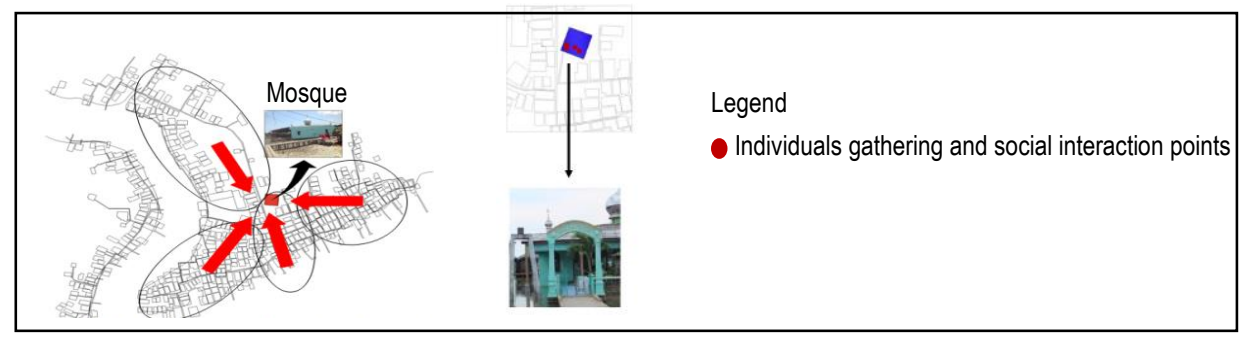


Fig. 11: Religious activities affect mosque establishment in which the mosque the spatial focus of settlement orientation

Observing from the aspects of environmental and economic activities, there are some areas serve as social facilities namely hall, integrated health post, temporary fish market, and other trading facilities. These places become one of the harbors to drop passengers who are visiting the fishing village in Belawan (Fig. 12). Economic and environmental activities become the accommodations for people to communicate and interact. Regulations, which are informal because they are created based on the villagers' perceptions, are created to accommodate those activities. That process impacts the space in a settlement (Erturk, 2011).

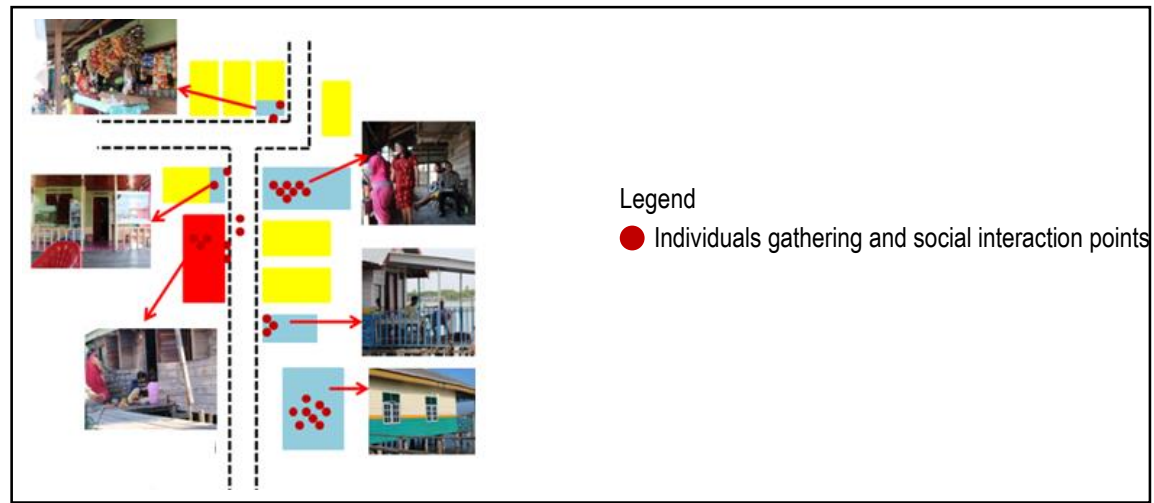

Fig. 12: Gathering points to interact with the public facilities resulting from economic activities such as shop and temporary fish market that is located close to villagers' houses

\subsection{Finding}

The development process of the fishing village in Belawan Medan from empty land to the establishment of the settlement in the micro to macro scale is an evolution process (Fig. 13). Evolution is the cause of the establishment of the settlement in this fishing. It comprises three stages which are colonization, dissemination, and competition (Fernandez, 2011). The first stage, colonization, occurs because an occupied region is no more able to accommodate the population increasing annually. At that moment, people start searching for a new unoccupied place and claim that place as their own. On the second stage, dissemination, the process of villagers' migration from their origin to the colonized land occurs. Bringing their offspring, they fill and occupy that empty land and that land eventually becomes a settlement. With the increasing population of villagers, therefore, on the third stage, the competition among villagers to obtain space occurs. This process of the third stage will produce a regularity of settlement pattern that will be made into a cluster.

Social influences have a role in the establishment of an unplanned settlement. They are social factor, cultural factor, economic factor, political factor, environmental factor, and safety factor. First, the social factors that affect the establishment of a settlement are human as social beings, human's adaptation toward the environment, population density, and access to education and health. Second, the cultural factors are people's point of view, culture, ethnic, caste, religion, needs and people's lifestyle as well as people's characteristic. Third, the economic factors are people's occupation, the existence of harbor that is the source of export-import, urbanization, industrialization, development of technology, availability and the value of land, standard of life, and the proximity to the center of activity. Fourth, the political factors are government, organization, society, and community. Fifth, the environmental factors are weather, climate change, the existence of tsetse flies, grazing land for livestock, the existence of gold and natural resources, also soil fertility. And the last, the safety factors are defenses against wild animals and enemies (Fig. 14).

The social condition of migrant community
Extended Family: The people who have stayed long in this village have offspring. After their offspring are married, they wish to keep interacting with their parents that they build their houses close to their parents'. As a result, a settlers group is formed.
Single Family: new comers come and stay in this village because of various aspects for instance occupation and etcetera. If they have offspring, they can make a settlers group. 


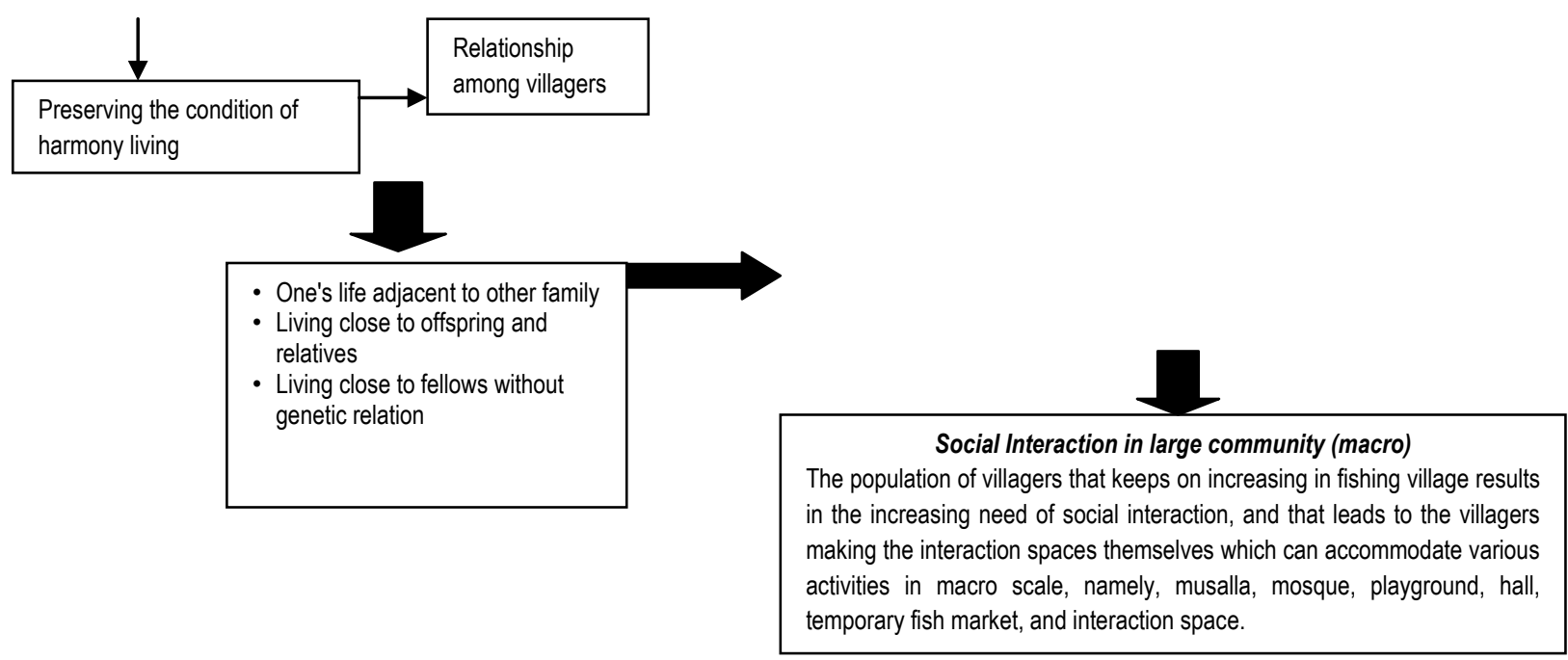

Fig. 13: An evolution process of the form of settlement from the result of the villagers' need for social interaction

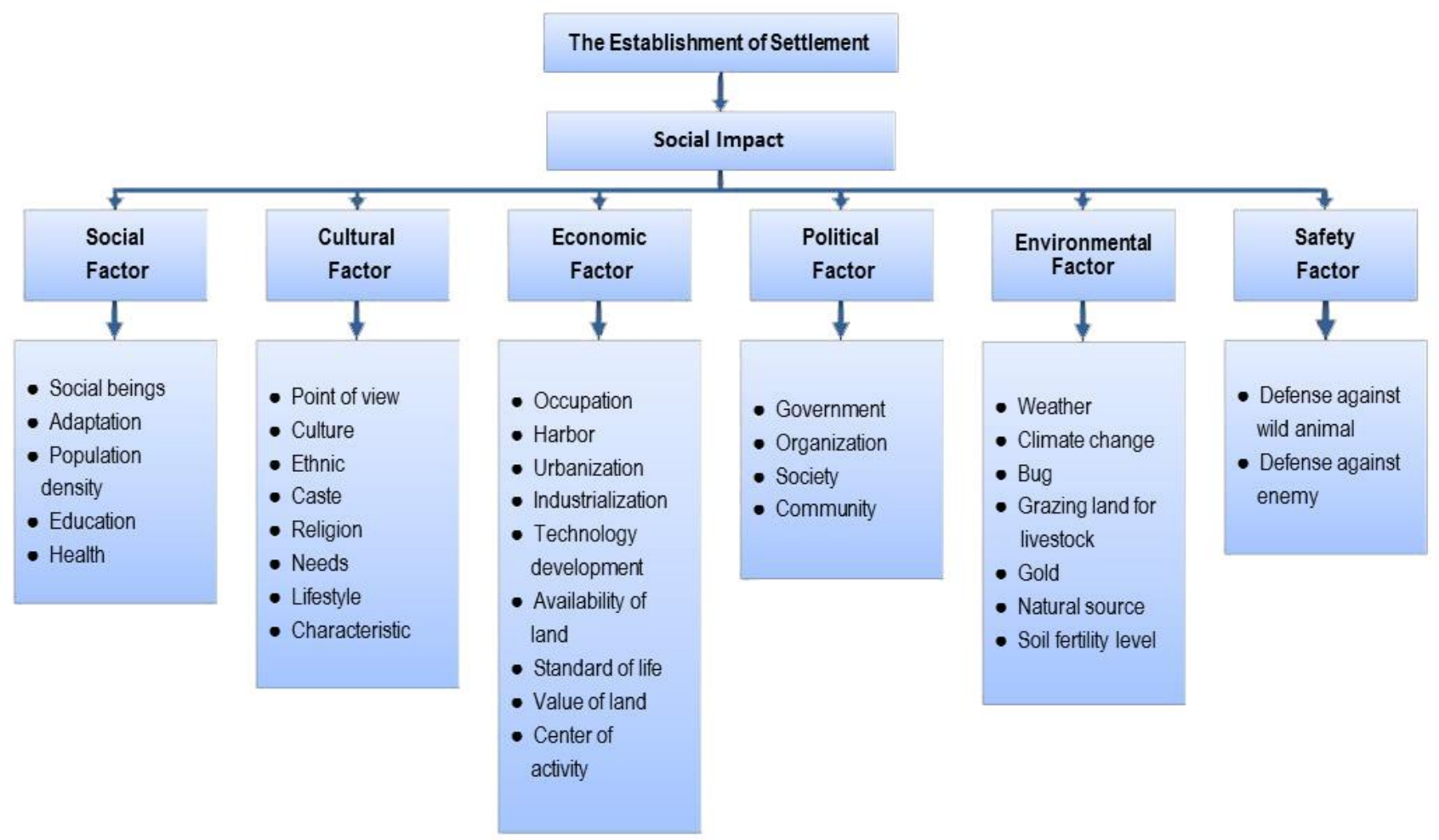

Fig. 14: Theoretical Concept of Social Impact towards the Establishment of Unplanned Settlement

\subsection{Conclusion}

Based on the theoretical concept that has been made, it can be stated that the social condition in a settlement tends to support its society to adapt to one's country easily. This ability can apply even though their social system changes and the culture they believe in degenerates. This theory is proved by Javanese, Bataknese, Malayan, Chinese, and other tribes in Medan City when they live at their place of origin with a low economic standard. The low economic standard becomes the motivation to establish a life near the Coast of Belawan Medan. Various ethics in Belawan Medan Fishing Village are pleased to socialize peacefully, calmly and in harmony, and also live close to their neighbors. They also have life enthusiasm in working hard to be able to survive in the society. Society's distinguished habit from various ethnics in this village is the habit of helping each other around the house. It is visible especially in preparing and executing parties or ceremony as well as in handling accidents or funerals. They are even accustomed to committing cooperation activities with some villagers to finish a project that is convenient for public interest (have the zest to voluntary work).

At the time when the villagers leave their origin settlement and occupy a new area, they will experience a social system change as the time flows. That change occurs because of the people's desire and action in their origin settlement to achieve a better life. Thus, 
as the time passes, there will be a change of mindset. There is thought that the society leaves their place of origin then occupies a new area. The society afterward goes there and builds the place which in time develops into a livable settlement. The tendency is the establishment of an unplanned settlement. It then gradually develops into a village.

Every individual and society as the dwellers of a new area have the desire to improve the environment they occupy, and this desire becomes the strength for a theory about the concept of characteristic occurrence of physical manifestation of a place as the society's social influence. Society as social beings has needs, namely obtaining the right to live, the right of ownership and the tranquility of life. That situation has become the fundamental social value of the society. Every community certainly has its characteristic of the social background associated with their land of origin. It affects the individual's personality in society. The personality that appears is encouraged by the lifestyles that simply become the pointers in themselves when choosing an action and decision in executing that action. Those pointers have a wide definition, starting from individual private scale, family, to society. The scope of pointers may change and depend on the interest, for instance, private interest, family interest, and society interest.

Society's social value in a settlement that affects individual's personality in an area will decide the orientation of life. Society's social value has stability and tenacity in coping with the change of social value. This situation is related to the mindset that is shown through the society's knowledge. It shows their way to solve a problem by studying a similar problem that has happened in the past. Then, the society starts thinking of the things needed to be done in the present time. Next, they think about the situation needs to be performed in the future after considering and studying the occurrences and mistakes in the past and present time. All those thinking processes are based on needs, and those create a thought that affects activities (traditional society's social condition) and the characteristic of settlement form.

The decisions made by the society occupying a new area have a connection with the context of the change in social culture after they have a plot of land in a new area. The form of settlement created is supported by the spatial strength and the movement of natural forces (Kwiatek, \& Soltys, 2011). The process of the establishment is affected by culture values, norms, attitude, concept, and views from the society who occupy an area that has the potential to develop into an unplanned settlement. Their strength, such as the shifting of villagers' choice and decision, will affect the form of settlement. In this case, this strength is affected by the social condition, economy, politic, and religion or belief. The conditions that affect each other are also potential to create the characteristic of a settlement because in there exists the role of the society's thought. These thoughts give spatial strength to the fishing village in Belawan Medan. The strength comprises directed strength (orientation, communication/relation, and gathering place) and undirected strength (teaching of physiology, and the spreading of placement). That theory supports the phenomenon that occurs on the structure and the form of residences and unplanned settlement (Oktay, 1998). The structure and the form of residences are shaped by buildings oriented towards the road, and the roads that connect one building to another, one space to another, and the existence of linear and centered spaces that serve as gathering and social interaction spaces for society. The irregular structure and form of residences depend on the environment physical condition (Achmad, Hasyim, Dahlan, \& Aulia, 2015). The structure and form become important parts in the development of an area. The development of a newly occupied area by comers happens one by one, bit by bit and continuously. Its start and end time cannot be predicted and known. This situation is related to society's social strength that underlying it (Aulia, \& Ismail, 2013). The process of the society's social change that occurs in the new area is not a part of a process that takes place step by step, but it is a comprehensive process. The social influence taking place in the society in the new area has a connection with the change of the believed system value. That condition certainly will affect the establishment of the development of the unplanned settlement in the new area that does not have any characteristic at first.

\section{Acknowledgements}

This scientific paper is one of the research product that is funded by Directorate of Research and Community Service; Directorate General of Strengthening Research and Development of the Ministry of Research, Technology and Higher Education. In the process of study of fishing village settlement in Belawan Medan, researcher cooperates with Wydia Ineke Sarsika as researcher's student.

\section{References}

Aulia, D.N., \& Ismail. A.M. (2013).Residential Satisfaction of Middle Income Population: Medan city. Procedia - Social and Behavioral Sciences, 105, 674-683.

Achmad, A., Hasyim, S., Dahlan, B., \& Aulia, D.N. (2015).Modeling of urban growth in tsunami-prone city using logistic regression: Analysis of Banda Aceh, Indonesia. Procedia - Social and Behavioral Sciences, 62, 237-246.

Besussi, E., Chin, N., Batty, M., \& Longley, P. (2010). The Structure and Form of Urban Settlements.

Creswell, J.W. (2008). Research Design: Qualitative, Quantitative, and Mixed Methods Approaches. California: Sage Publications, Inc.

De Bustillos, Liana. A., Santosa. H., \& Napier, M. (2005). Sustainable Livelihoods in the Informal Settlements. CIB General Secretariat: CIB Report.

Drolet, J., Robertson, J., \& Robinson, W. (2010). Settlement Experiences in a Small City: Voices of Family-class Immigrants, and of Settlement Workers. Canadian Social Work, 12, 218-223.

Erturk, S.A .(2011).The settlement characteristics of Bursa plain and its environs. Procedia - Social and Behavioral Sciences, 19, $371-380$. 
Fernandez, R.F. (2011). Physical and Spatial Characteristics of Slum Territories Vulnerable to Natural Disaster.

Ginting N. (2016). How Self-efficacy Enhance Heritage Tourism in Medan Historical Corridor, Indonesia. Procedia - Social and Behavioral Sciences, 234,193-200.

Kwiatek A., \& Soltys.(2011).Small towns in Poland - barriers and factors of growth. Procedia - Social and Behavioral Sciences, $19,363-370$.

Larcombe K., \& Yan, M.C., (2010). A Place-based Approach to Social Integration: How a Neighbourhood House Works with Newcomers. Canadian Social Work, 12. 170-175.

Marpaung, B.O.Y. (2016). Communication Strategy Planning of Fisherman Kampung Medan Belawan as a Tourist Destination. Procedia - Social and Behavioral Sciences, 234, 344-352.

Marpaung, B.O.Y., \& Harahap, M.(2016).The Structure of Unplanned Settlements In Badur Village, Medan, Indonesia. International Journal of Academic Research, $4,177-187$

Nasution, A.D., \& Zahrah,W. (2015).The Space is Not Ours, the Life of Public Open Space in Gated Community in Medan, Indonesia. Procedia - Social and Behavioral Sciences, 202, 144-151.

Oktay D. (1998). Urban Spatial Patterns and Local Identity: Evaluation in a Cypriot Town. Open House International, 23, 1-7. 